\title{
The Theory of Polanyi's Free Market Path:a Practice of China's Land, Labor and Monetary Reform
}

\author{
Zhenli Wang* \\ School of Development Studies \\ Yunnan University \\ Kunming, China \\ 309616077@qq.com
}

\author{
Jianyu Lin \\ School of Development Studies \\ Yunnan University \\ Kunming, China \\ ljysociology@163.com
}

\begin{abstract}
Karl Polanyi stresses that the establishment of the free market is dependent on the formation of the state compulsory intervention, and since ancient times, there has been no such thing as completely free, self-regulating market system, and the claim of spontaneous adjustment market is a thorough utopia. Based on a series of Chinese reform measures in the eighties and nineties (of the 20th century), it can be found that the evolving path of Chinese free market economy, just like what Polanyi said, has been relying on the state's intensive and extensive power, rather on the spontaneous free market mechanism. Therefore, without the compulsory intervention force, the system of socialist market economy cannot spread out as we witness today.
\end{abstract}

Keywords-government power; intervention and control; freedom; market economy

\section{INTRODUCTION}

Karl Polanyi was born in a Jewish family in Hungary, and he was one of the most distinguished and most discriminating economic historians in the twentieth century. Many of his works reflected and criticized the defects of the free market in the capitalist world system. He believed that there was a conflict between the free market and social ethics formed in the period from the nineteenth century to the early twentieth century and social ethics at that time, which resulted in many contradictions and disturbances. By the end of the twentieth century, the conflict had ended with World War II finally, and the free market had destroyed the civilized society at that moment. Therefore, Polanyi made great efforts to assail the unconstrained free market, advocated that the government should regulate the free market, and insisted that the Communist society would eventually lead people to where there is the real freedom, justice and equality.

In the history of the development of market economy, the concept of "double movement of market and social protection", which was originally put forward by Polanyi in his book The Great Transformation: The Political and Economic Origins of Our Time, was a classic proposition --When the free market was expanding constantly and frantically, another power aimed to protect the society was emerging gradually, which not only could effectively prevent the invasion of the market, but also was essential to guarantee a harmonious development of social protection.

Nowadays, the theory of "double movement" originated by Polanyi has been well known, and Polanyi is regarded as a pioneer supporting that governmental power should be adopted in controlling the free market. The executive power of the government, in Polanyi's opinion, seems to be one counter force that restricts the free market. Many readers, however, have misunderstood and neglected the other arguments of Polanyi, that the formation of laissez-faire and self-adjusting market is enforced by the state, and that the free market is strictly governed and compulsively interposed by the state. "The road to the free market is relying on a large number of long-term and unified plannings of the interventionism, in order to make it open smoothly and fluently." [1] This is a further demonstration of Polanyi's argument that the "selfregulating market has never really existed", and that "the idea of a self-adjusting market implied a stark utopia". As is mentioned in The Great Transformation, in a pre-capitalistic society, economy, whose activities are subject to a variety of social relations, is deeply embedded in social, political and ethical relations, and moreover, human economic behavior is also attached to their social relations. Although the idea that economy can be effectively disembedded from society has been highly praised by the economists in the period of classical capitalism, the occurrence of regulation and market is simultaneous, and self-adjusting market against the prevailing trend, is merely a beautiful theory which has never come true [1]. At that time, governments were limiting the formation of free markets as much as possible, so the free market is not spontaneous. In other words, there would be no possibility of free market if situation developed naturally, and the smooth degree of this road also depended on the continuous increase of regulatory forces implemented by national governments [1].

\section{Polanyi's Elucidation AND ProOF}

The important point that the government is not only an "administrator" regulating the free market, but also an "pathbreaker" pushing forward the establishment of the free market, shows that the power of governmental intervention has a strong duality and so does governmental functions, which has

\footnotetext{
* Corresponding author
} 
long been overlooked. Rather than a result of self-development through withdrawing the role of government, the free market can arise from the conscious and frequent intervention of governments, which has been gradually demonstrated in Polanyi's book The Great Changes.

\section{A. The Liberalism Trend Prefers Government Intervention to Exit}

In the 1820 s, there was a trend of liberalism in Europe. Liberals believe that the market is natural and can be formed automatically, as long as it is not disturbed by subjective activities. But the reality is not the case. When the market system has not been established, economic liberals will do their best to call on the intervention of government without hesitation, so that the market order can be built perfectly. Hence, without wavering their long standing position, economic liberals can appeal to the state for establishing the self-regulating market by means of intervention, which brings about the birth of Trade Union Act and Anti-trust Act; What's more, it is a prerequisite under certain conditions that a selfadjusting market can be created by resorting to violent war. For example, during the American Civil War, an armed force has been exploited by the northern states to set up a free labor market.

In the view of some enlightened liberals, the maintenance of the free market cannot exclude the forces of governmental intervention, and it is not incompatible between free market and regulation. They see that the establishment and improvement of the self-regulating market is in need of such interventions, and even coercive measures must be taken when carrying out some anti-trust policies. They also know that the self-regulating market, as an orderly economic system, characterized by an orderly and unconstrained structure, cannot be produced without the supervision and management of the state. Therefore, despite strong aversion to governmental power in somebody's heart, they, in fact, have to hand over the new power, rising institutions and normative systems to the government for the sake of building a self-regulating market [1]. Meantime, the government is willing to play such a role, because the intervention and management of the economy can greatly enhance the country's administrative functions.

\section{B. Government's Repeal of "Protective" Regulations}

When the trend of liberalism has become intenser and intenser in Europe, European liberals burst out greater enthusiasm for reform, and they have been making a claim for more right of discourse, in order to build some kind of systems in tune with the development of the times and to abolish the restrictions of the regulations. For instance, David Ricardo insisted on abolishing the subsidy system in his book On The Principles of Political Economy And Taxation; The British Settlement Law was repealed in 1795,because the British industrial capitalists at that time thought that the Law of Settlement severely restricted the flow of workers; In 1814 in British, the Statute of Artificers was abolished; In 1832, the British industrial bourgeoisie entered the parliament, and after the reorganization of the Congress , a series of "protection law" was repealed, and the subsidy system was abolished, which "liberated" the productive forces. As a result, labor force became free commodities, and free market sprang up quickly, promoting the development of capitalism.

In the 1830 s and 1840s, European governments were carrying out the abolishment, rebuild, and reconstruction of all kinds of laws and regulations, which opened a new era of reform. In the 1830s, the British bourgeoisie began to require the revision of Act of Relief, because it prevented the rise of the industrial working class, which was paid based on their labor forces.[1] However, Act of Relief provided subsidies for civilians, leading to a low degree of work enthusiasm. In 1834, the New Act of Relief was passed, and the indigent were divided into material poverty-stricken people and independent workers. The former were housed in the workhouse, and on humanitarian grounds, the poor should be given relief supplies; the latter were not allowed to give aids, and they must earn wages by selling their labor. The purpose of the cruel method is to force people to work and learn to work for survival, potentially bringing to a liberation of labor.[1] In the same year, Speenhanland Law was also abolished, which could be regarded as a social protective act, and it was also a measure to prevent market expansion under governmental intervention. Since this act came into effect, the freedom of the labor market was impeded.

Through a series of repeal of the bills, Polanyi has demonstrated his point of view--the emergence of the free labor market in human history is only in the nineteenth century, which has a very short history. The liberals and capitalists know that only by destroying the traditional protective mechanism of the labor force completely, can a free and competitive labor market be founded. The original laws and regulations have effectively prevented the creation of a free and competitive labor market in Europe, which makes the labor force non-commercial. Once they were abolished and withdrawn immediately, a liberated labor market is reluctantly born in the continent of Europe and people eventually become free-floating commodities. All these can be true, contributing to all kinds of strong legislation pushed by countries, just as Polanyi says, "the interferential focus is to maintain some simple aspects of freedom, such as land, labor, money, and the urban administrative system"[1].

\section{A CASE OF STUDYING CHINA'S MARKET ECONOMY CONSTRUCTION}

China's reform road of socialist market economy can be ascribed to the governmental intervention, opening the door of Chinese market economy step by step. Although the obstruction, social protective power, would make it difficult to continue further, the Central Committee of the Communist Party of China has endowed these policies and regulations with legitimacy and authority, which reflects the national compulsive intervene. Only in this way, can a self-regulating market be built in China.

In retrospect, the first step of building a Chinese selfregulating market is to open up the commodity market, reforming the system of commodity price. In 1986, the reform of contractual wage system was actually the process of labor commercialization, releasing the free labor force; In the 1980s, 
land ownership and managerial authority were separated, and in the 1990s, Teng Hsiao-ping's southern tour speeches turned on a proceeding in commercialization of land ownership, giving rise to a rapid development of commercial housing construction; Funds are on the way of commercialization , and bank loans become more liberal and flexible without relying on the approval [2].Therefore, the process of China's market reform is, as Polanyi said, making these virtual goods--land, money, and labor commercial, thus establishing a socialist market economy in China.

\section{A. Land Policy Reform}

At the first, the Land policy reform occurred in rural areas, when the central government saw that the agricultural production is inefficient and farmers' lives are in a very embarrassing situation. Based on the seriousness and urgency of the reality, the central leaders are actively exploring a feasible plan for the separation of land ownership and management rights, so that the land property rights become free and flexible. After the Third Plenary Session of the 11th Central Committee of $\mathrm{CPC}$, the central government, in December 1978, launched the CPC Central Committee's Decisions on Accelerating the Development of Agriculture (Draft) and Rural People's Communal Regulations (Draft), emphasizing the establishment of responsible system on agricultural production, and allowing that "contracting output quotas to work groups", but "household responsibility system" still belonged to the political forbidden zone, strict restrictions on land beginning to loosen [3].

In the years between 1980 and 1983, CPC Central Committee issued Notifications On Further Strengthening And Improving The Agricultural Responsibility System, Summary of the National Rural Work Conference, Some Problems on the Current Rural Economy and other documents, making a full discussion of "household responsibility system", and affirming the freedom and initiative of the "household responsibility system". Therefore, some areas began to carry out these documents as a experimental unit and promote the household contract responsibility system to other areas. By the end of 1984, a drastic reformation of the people's communal system had been accomplished. For example, the system of township construction had been restored, and household contract responsibility system had become a national policy, which marked a historic breakthrough in rural land reform [4].

In the early1990s, the CPC Central Committee passed the CPC Central Committee's Decisions on Further Strengthening Agricultural And Rural Work and Agricultural Law; The government has introduced a series of benefiting-farmers policies, and adhered to preferential policies for farmers, such as, responsibility system of contracted management of rural land and double-level management system of unificationdecentralizaiton integration, allowing farmers to possess the lease-holding right of productive projects and transfer the right of land tenancy legally. The CPC Central Committee liberated the farmers from the stiff system of production team and commune, so that farmers got more autonomy for planting and surviving, which was of great significance to the development of rural economy and the establishment of socialist market economy.

\section{B. The Establishment of Free Labor Market}

The emergence of China's free labor market is put down to governmental coercion. Firstly, through a series of rural land reform, farmers can be liberated from the collectivization, and the most important and long-term contribution of noncollectivization, is to enable farmers to regain economic freedom; Secondly, the loosening of the rural household registration management has made the farmers flow freely and lifted the restrictions on immovable farmers in rural areas. As a result, a large number of labors can be transferred from rural areas to urban regions, from rural posts to off-farm jobs.

In 1981, the reform of state-owned enterprises made the original fixed workers movable, by the way of a contract responsibility system. With the continuous deepening of the reform of state-owned enterprises, the Chinese government has decided to carry out the reform of personnel management. The so-called "iron rice bowl"(system of lifetime employment), prevailing in the past, was broken sharply, in the wake of contractual system promotion rapidly. By 1984, the implementation of the contract responsibility system had spread all over the country, and a contractual agreement was signed between the employees and the director of state-owned enterprises, which leads to a formal performance management. In December 1986, the State Council allowed the state-owned enterprises to adjust wages and benefits based on the performance of the employees, with the total salary fixed. Consequently, the labor market presented a more flexible momentum. At the same time, a multi-layer contractual system of distribution according to work is gradually formed in the state-owned enterprises [3].

In the middle 1990s, the further reform of state-owned enterprises was carried out quickly, such as, "retain the large ,release the small" and "reduce the employee, promote the efficiency", that is to say, "managing and invigorating the large enterprises while relaxing control over small ones". By adjusting the structure of the institutions and streamlining the bloated structure of staff, a considerable part of the labor force got back to the market again, abiding by fair competition and the survival of the fittest which was the law of market economy. Such measures were taken to break the original solidified, rigid structure of the labor supply and reallocate labor according to market demand. Only in the forceful hand of the governmental macro-control, can all of these come true. [2]

\section{Monetary System Reform}

Banking reform is the most important aspect of the monetary system reform. Before 1978, there was only one bank --the People's Bank of China, which was owned by the central government and supervised by the Ministry of Finance. Its main function was to provide financial support for the production plan of state-owned enterprises. Due to the planned economy system, no savings deposits existed in national hands, and it was impossible to have much demand for the banking sector [2]. Until 1979, the government had decided to reform the banking sector, and the people's Bank of China, merely as a financial cashier, could not adapt to the new economic system. It is urgent to break the unitary system of the central bank, and set up the specialized bank to divide the function of 
the people's Bank of China, and construct the standard doubledeck bank system to make it more flexible and suitable. Thus, Agricultural Bank of China was established in February 1979, with the Notice on the Resumption of Agricultural Bank of China issued, and the Agricultural Bank of China was mainly responsible for the handling of agricultural and rural related businesses; In March, Consulting Report on the Reform of the Banking System in China was adopted by the State Council, announcing that the partial sector in charge of foreign trade and investment was separated from the People's Bank of China; In August of the same year, the China Construction Bank, which was responsible for dealing with fixed capital investment, was out of control of the Ministry of Finance and became independent; In 1984, the State Council issued the Decisions on Endowing the People's Bank of China With the Exclusive Functions of the Central Bank, and ICBC was established. Newly formed ICBC was responsible for handling all commercial transactions except involved aspects of other three banks.

At this point, the People's Bank of China in coordination with four state-owned banks, had built a new double-level banking system, in which the People's Bank of China became the central bank, supervising and managing other commercial bans, and four state-owned banks took over the general deposit and loan business gradually. All of these procedures declared that the banking system reform of China preliminarily completed at the beginning of reform and opening up. In the late $1980 \mathrm{~s}$, the four state-owned banks began to infiltrate each other through private business, showing a positive adaptation to the new situation of market competition. Thus, the autonomous competition between them began to appear.

At the beginning of 1990s, under the leadership of the government, not much change took place in Chinese banking industry, and the bank set up branches and sub-branches in accordance with the administrative regions. The interest rates for deposit and lending was determined by the government and the establishment of branches also needed to be approved by the government [5]. Then the state decided to open the second round of banking reform. The aim of the second reform was to give more autonomy to the four state-owned banks in granting loans, and to further enhance the initiative and competitiveness of the banking sector, so that it can adapt to all kinds of changes in the free market. In 1992, the state announced that the loan business was open to private enterprises, and there was no limit to the number of loans. In addition, the central bank only stipulated the annual credit lines of each bank, and the specific form of granting loans was casual. In 1994, policy banks were introduced, which can sell bonds directly on the market in response to the market dynamics. In 1995, "Commercial Bank Law" was passed, whose adoption marks the development and supervision of China's commercial banks into a legal and standardized track.

Now, the state's macro-control of the money market is achieved through the establishment of a sound monetary system and flexible monetary policy. Through the control of the interest rate, the monetary system administrates the pulse of economic operation from the micro, meso and macro level, and provides the impetus for the healthy operation of the national economy. At the micro level, the central bank carries out monetary policies, and governs three main interest rates, so that the amount of money in circulation in the market and cost of capital borrowing can be grasped in the standard scope; At the meso level, the flow of money in the market enters the field of investment or savings depending on interest rates. Meanwhile, investment in different industries has a different sensitivity to interest rate; At the macro level, the products produced and created by different industries are exchanged with the currency in the hand of residents in the market, which may bring about macroeconomic inflation or deflation. The specific operation mechanism is shown in figure 1 .

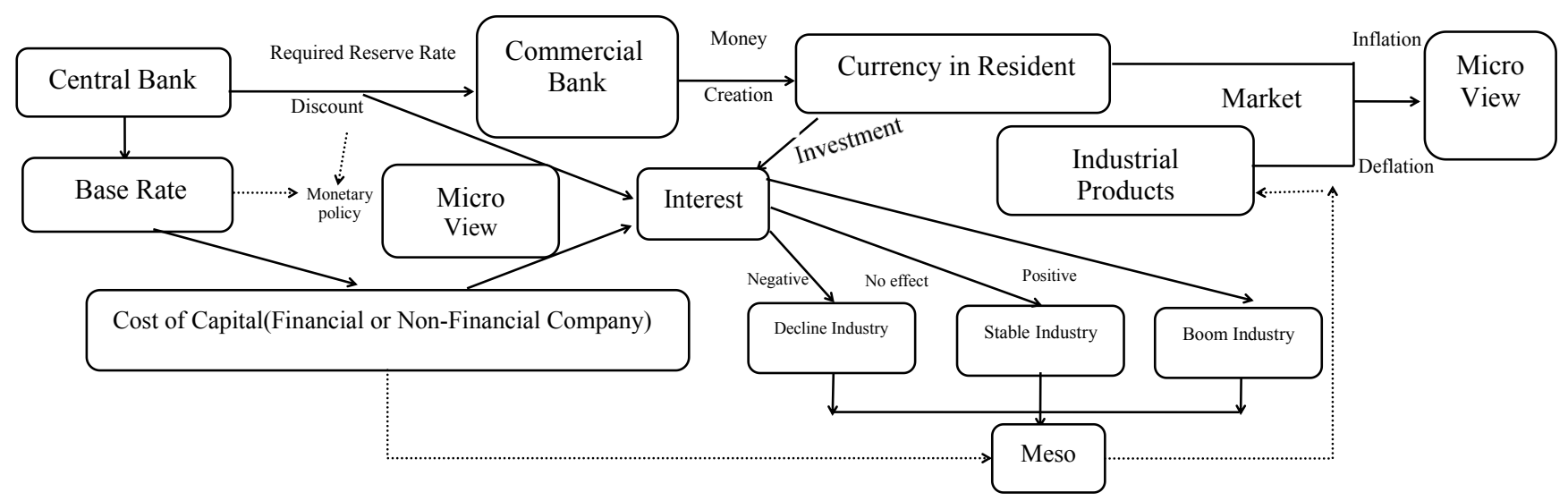

Fig. 1. The specific operation mechanism of monetary market.

IV. CONCLUSIONS
American scholar, Laurence Brahm, describes China's market economy as "a managed marketization", which means that the market has been under the impact of the government in 
the process of building a market economy [5]. Under the influence of the national government intervention, China's labor force, land and money are gradually moving towards commercialization, and a self-regulating market mechanism is established, just as Polanyi says.

However, the establishment of such a free market is completely pushed by the state intervention. In other words, the socialist market economy will not be formed without the strong control of country. All in all, whether self-regulating market or interventional market is the embodiment of the state behavior in the market. The free market has never appeared; The free market is not natural, and it is just the result of governmental intervention; [6] When the rapid development of free market, a reverse movement comes into being, which is a manifestation of governmental will. Whether the market toward freedom or intervention, is a product of government behavior [7]. Although the laissez-faire economy is caused by the governmental plan and need, restrictions on laissez-faire economy later come naturally.

China's reform and opening up is a great decision. The content of reform and opening up involves economic, political, cultural and other aspects, involving all aspects of people's lives. This paper only chooses three factors--labor, land and monetary to discuss, without other factors involved, so the description of China's reform and opening up is not comprehensive enough. In this paper, China's reform and opening up is taken as an example to verify Polanyi's free market construction path, but it is noted that China's reform and opening up is carried out under the national conditions of the primary stage of socialism in China and has its special features. Of course, every country is different, every problem particular. The real situation in China is not completely in conformity with the theory of Polanyi, nor is it in accordance with the free market path of capitalist countries. But everything has its general character and individual character, developing and change, track of national reform is not exceptional also.

\section{REFERENCES}

[1] Karl Polanyi, "The Great Transformation: The Political and Economic Origins of Our Time," translated by Shumin Huang, Beijing: Socia Science Literature Press, 2013.

[2] S.G. Wang, "Polanyi's Great Transformation and Chinese Great Transformation," Shanghai: SDX Joint Publishing Company, 2012.

[3] H. Ronald, N. Coase, "Changing China: the Road of Market Economy in China," translated by Yao Xu and Zhemin Li, Beijing: Citic Press, 2013.

[4] Z.M. Chen, "Discussions on the Formation of the Basic Economic System of Socialism with Chinese Characteristics," Beijing Party History, 2015, pp. 16-22.

[5] Y.H. Qiao, P. McGowan, M. Duikin, Y. Liu, "Review the Process of Chinese Government's Decentralization to Banking Sector," Journal of Northeast Normal University (Philosophy and Social Sciences Edition), 2015, pp. 73-78.

[6] G.S. Bao, "Reflections on the Nine Propositions of Polanyi's 'Great Transformation'," Zhejiang Social Sciences, 2014, pp. 4-14+21+155

[7] J. Zhao, "The Myth of the Free Market: Start with Polanyi's 'Great Transformation'," Journal of Zhengzhou University (Philosophy and Social Sciences Edition), 2009, pp. 112-114 